\title{
Immunohistochemical Study of IMP3 Expression in Laryngeal Squamous Cell Carcinoma
}

\author{
Wala'a Ahmad Al-Sayed Ashmawy*, Ahmed Mahmoud Abd-Elaziz, Amira Mohamed Bassam, Heba Abdelmonem Ibrahim \\ Department of Pathology, Faculty of Medicine, Cairo University, Giza, Egypt
}

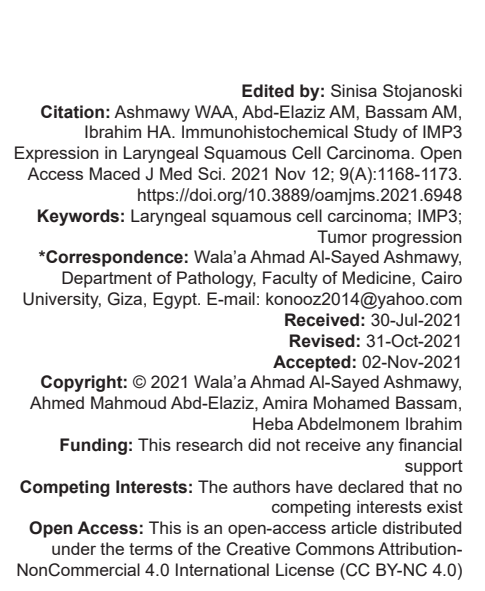

\section{Abstract}

BACKGROUND: IMP3 is an RNA binding protein, which is strongly expressed in malignant tumors, promoting tumor cell proliferation.

AIM: The aim of the study was to evaluate the expression of IMP3 in laryngeal squamous cell carcinoma (SCC) and to correlate the expression of IMP3 with available clinicopathological data.

METHODS: Sixty one total laryngectomy and laryngoscopic biopsies; collected from the Pathology Department Faculty of Medicine, Cairo University. Two slides were prepared from each paraffin embedded tumor block, one slide for Hematoxylin and Eosin staining, and the other for immunohistochemical staining by IMP3 polyclonal antibody.

RESULTS: Thirty-seven cases $(60.7 \%)$ showed positive IMP3 expression, and a statistically significant correlation was found between IMP3 expressions in normal, dysplastic epithelium/in situ component, and the invasive malignant tumor tissue. Correlations between IMP3 expression and other available clinicopathological data were all non-significant.

CONCLUSION: This study suggests that IMP3 might play a role in laryngeal SCC carcinogenesis and progression process from normal to dysplastic to malignant epithelium, and thus IMP3 might be targeted by gene therapy.

\section{Introduction}

Most of head and neck cancers (HNCs) are classified as squamous cell carcinoma (SCC), which is the sixth most common malignancy in humans, and approximately 600,000 people develop some form of HNC and about 300,000 people die of this cancer each year [1].

The larynx is a part of the head and neck, and laryngeal carcinoma is one of the most common malignant tumors in the upper aerodigestive tract [2] with a total of 159.000 new cases of carcinoma per year, more commonly affecting males [3], [4], [5], in whom it comprises $2.4 \%$ of cases and $2.1 \%$ of deaths [6]. The incidence of laryngeal SCC (LSCC) has been reported to increase, with a considerably more frequency in middle-aged and elderly men [7] with the peak incidence in the sixth and seventh decades of life, it accounts for $85-95 \%$ of laryngeal malignancies [8]. In Egypt, laryngeal cancer occupied the second rank among all the respiratory cancers [9].

Smoking, particularly of cigarettes and alcohol consumption are the major risk factors for laryngeal cancer. Human papilloma virus (HPV) infection, particularly HPV16 subtype, is also associated with LSCC [10].
The pathological mechanism of LSCC is complicated and involves genetic, epigenetic and environmental factors [11]. DNA methylation is significantly related to the development of LSCC [12].

There are four major types of laryngeal carcinoma; transglottic carcinoma [13], glottic, supraglottic, and subglottic carcinoma [8].

The overall 5-year survival rate for patients with LSCC is almost $61 \%$ as reported by SEER 18 registries, National Cancer Institute, 2016 [14].

The mammalian IMP family (insulin-like growth factor 2 mRNA binding protein, IGF2BP), is identified as a modulator of mTOR signaling and IGF2mRNA translation [15], and comprises three RNA- binding proteins [16], namely, IGF2BP1 (IMP1), IGF2BP2 (IMP2), and IGF2BP3 (IMP3) [17]. Structurally, the members of this family have a conserved domain structure, including two N-terminal RNA recognition motifs and four C-terminal domains [16]. The C-terminal domains are essential for RNA-binding and thereby determine the subcellular localization of all three members, which exhibit a high degree of identity and even high similarity at the amino acid level, and are typically characterized by a mainly cytoplasmic, granular distribution [18]. Only one report suggested that IMP3 modulates the fate of cyclin D1, D3 and G1 encoding transcripts in 
the nucleus [19], this may be due to aberrant nuclear staining of some commercial antibodies [18].

IMP3 is proposed to be a potent posttranscriptional oncogene [17] that is strongly expressed in malignant tumors [20], promoting tumor cell proliferation by enhancing the expression of cyclins [19], and enhancing tumor cell aggressiveness [20].

IMP3 has been correlated with an aggressive and invasive cancer phenotype in some human malignancies, such as lymphoid cancers [21], ovarian carcinoma [22], thyroid cancers [23], oral SCC [24], [25], osteosarcoma [26], breast cancer [27], endometrial clear cell carcinoma [28], hepatocellular carcinoma [29], skin cancers [30], central nervous system cancers [17], gastrointestinal tumors [31], and lung cancer [32].

\section{Materials and Methods}

This is a retrospective cross-sectional study in which the material was retrieved from the paraffin blocks of 61 LSCC patients, obtained from Pathology department, Faculty of medicine, Cairo University, during the time period from January 2017 till December 2017. Specimens obtained were total laryngectomies and laryngoscopic biopsies, 24 cases of which were associated with selective neck dissection.

Data collected from the patients sheets included: Age, sex, tumor site and size, histological type, tumor grade, depth of invasion, and presence of lymph node metastasis.

Tumor paraffin blocks were sectioned at $5 \mu \mathrm{m}$ thickness and some sections were mounted on glass slides and stained with Hematoxylin and Eosin. Sections with the most pronounced tumor thickness were submitted on charged slides for immunohistochemistry.

\section{Immunohistochemical staining for IMP3}

- $\quad$ The staining steps and incubation times were preprogrammed into the Autostainer Link software (Dako autostainer link 48).

- Mouse polyclonal anti-IMP3 antibody (SNF Medical, dilution 1: 400 to 1:800) was used.

The positive control for IMP3 was pancreatic adenocarcinoma.

\section{Evaluation of expression of IMP3}

In normal tissues, a cell type specific distribution of IMP3 expression was recorded, and the staining intensity was estimated as positive (+), or negative (-). In tumor tissues, cytoplasmic or nuclear staining was evaluated by staining intensity $(0,1+, 2+$, and $3+)$, and the fraction of positive tumor cells was scored for each tissue spot. A final score was built from these two parameters according to the following criteria: negative scores had a staining intensity of 0 and $1+$ in $\leq 10 \%$ of tumor cells; weak scores had a staining intensity of $1+$ in $>10 \%$ and $\leq 70 \%$ of tumor cells or a staining intensity of $2+$ in $\leq 30 \%$ of tumor cells; moderate scores had a staining intensity of $1+$ in $>70 \%$ of tumor cells, a staining intensity of $2+$ in $>30 \%$, and $\leq 70 \%$ of tumor cells or a staining intensity of $3+$ in $\leq 30 \%$ of tumor cells; and strong scores had a staining intensity of $2+$ in $>70 \%$ of tumor cells or a staining intensity of $3+$ in $>30 \%$ of tumor cells. All tumors exhibiting at least weak expression were defined as IMP3-positive [33].

Tumor tissue sections from each sample were examined under the microscope at high power magnification, for the presence of cytoplasmic or nuclear brown staining of IMP3. Normal, dysplastic epithelium and in situ components were evaluated for IMP3 expression as well. The results of IMP3 immunostaining in the tumors were correlated with other clinicopathological factors included in the study.

\section{Statistical analysis}

- $\quad$ Microsoft Excel 2013 was used for data entry and the Statistical Package for the Social Science (SPSS version 24) was used for data analysis.

- Simple descriptive statistics (arithmetic mean and standard deviation [SD]) used for summary of normal quantitative data and frequencies used for qualitative data.

- $\quad$ Bivariate relationship was displayed in cross tabulations and Comparison of proportions was performed using the Chi-square and Fisher's exact tests where appropriate.

- $\quad$ Paired T-test, one-way ANNOVA, and posthook tests were used to compare normally distributed quantitative data.

- $\quad$ The level of significance was set at probability (p) value $<0.05$.

\section{Results}

This study is a retrospective cross-sectional study, conducted on 61 cases of LSCC obtained from laryngectomies (28 cases) and laryngoscopic biopsies (33 cases).

Fifty nine cases were males and two cases were females. Their ages ranged from 40 to 76 years, with mean age of 59.21 years $\pm 7.47 \mathrm{SD}$. Tumor location was documented in 57 cases only, the most common location was the glottic region, representing (57.9\%), 
followed by the supraglottic region $(21.1 \%)$, while the subglottic region was the least common location (3.5\%). Maximal tumor diameter was documented in 28 cases only; it was $<3.53 \mathrm{~cm}$ in $60.7 \%$ of cases. Histological grade of tumors was documented in all cases; Grade II was the most commonly encountered, representing $80.3 \%$ of cases. ( $\mathrm{T}$ ) Stage could be assessed in 28 cases only, most of them $(39.3 \%)$ were stage T3. Selective neck dissection was documented in 24 cases only; most of them (62.5\%) were NO.

The pathological characteristics of the studied cases are summarized in Table 1.

Table 1: Pathological characteristics of the studied cases

\begin{tabular}{ll}
\hline Pathological characteristics & Number (\%) \\
\hline Tumor location & $12(21.1 \%)$ \\
Supraglottic & $33(57.9 \%)$ \\
$\quad$ Glottic & $2(3.5 \%)$ \\
Subglottic & $10(17.5 \%)$ \\
$\quad$ Transglottic & \\
Maximal tumor diameter & $17(60.7 \%)$ \\
$<3.53 \mathrm{~cm}$ & $11(39.3 \%)$ \\
$\geq 3.53 \mathrm{~cm}$ & \\
Histological grade of tumor & $4(6.6 \%)$ \\
Well differentiated (Grade I) & $49(80.3 \%)$ \\
Moderately differentiated (Grade & \\
II) & $8(13.1 \%)$ \\
Poorly differentiated (Grade III) & \\
T stage & $4(14.3 \%)$ \\
T1 & $8(28.5 \%)$ \\
T2 & $11(39.3 \%)$ \\
T3 & $5(17.9 \%)$ \\
T4a & \\
Lymph node metastasis & \\
Positive & $5(20.8 \%)$ \\
N1 & $4(16.7 \%)$ \\
N2 & $15(62.5)$ \\
Negative &
\end{tabular}

Regarding IMP3 immunostaining, 37 cases $(60.7 \%)$ showed positive IMP3 expression and negative expression was noticed in the remaining 24 cases $(39.3 \%)$, with all Grade I tumors showed negative IMP3 expression and positive expression was noticed to increase with increasing histological tumor grade Figure 1.

Stromal fibroblasts, smooth muscles, and mucous glands of the larynx were noticed to be positive for IMP3 expression, and these were considered as positive internal control for IMP3. Membranous staining of IMP3 was noticed in addition to cytoplasmic or nuclear staining.

Normal epithelium was present in 46 cases only (38 cases of them; $82.6 \%$ ) showed negative IMP3 expression in normal tissue. Normal, dysplastic epithelium, in situ component and malignant tissue were all present in 26 cases only, (20 cases; 76.9\%) showed negative expression in normal tissue. Statistical analysis using Chi-square test revealed statistically highly significant positive correlation between IMP3 expression in cases with normal epithelium and invasive malignancy, and in cases with normal epithelium, dysplastic epithelium, in situ component and invasive malignancy, emphasizing that IMP3 plays a role in tumorogenesis.

Dysplastic epithelium or in situ component was present in 34 cases only, 24 cases of them; $(70.6 \%)$ showed positive expression in a nearly similar percent

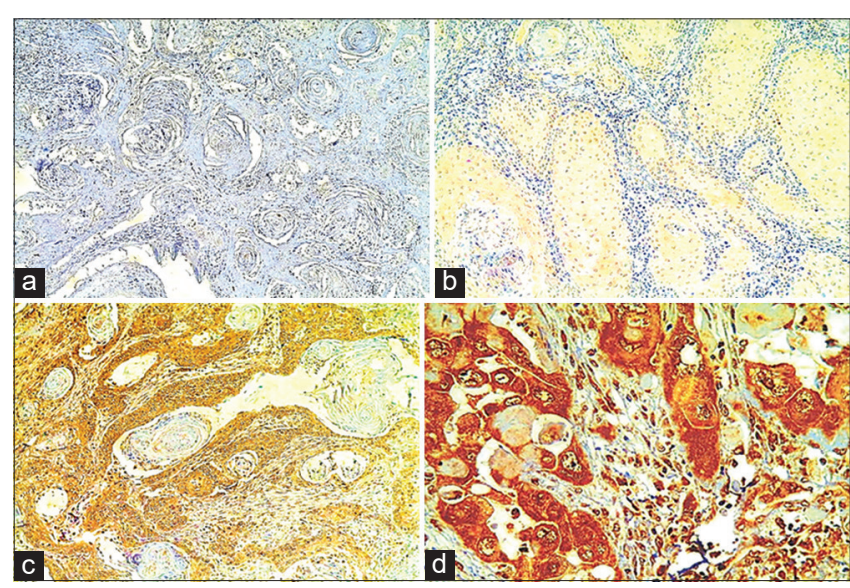

Figure 1: IMP3 expression in various histological grades of laryngeal squamous cell carcinoma. (a): Invasive well differentiated laryngeal squamous cell carcinoma, Grade I, with negative expression of IMP3, showing no staining of tumor cells. (Low power). (b): Invasive moderately differentiated laryngeal squamous cell carcinoma, grade II, with moderate positive expression of IMP3, showing weak intensity in $>70 \%$ of tumor tissue (Low power). (c): Invasive moderately differentiated laryngeal squamous cell carcinoma, Grade II, with strong positive expression of IMP3, showing strong intensity in $>30 \%$ of tumor tissue (Low power). (d): Invasive poorly differentiated laryngeal squamous cell carcinoma, Grade III, with strong positive expression of IMP3, showing strong intensity in $>30 \%$ of tumor tissue (High power).

to invasive malignancy which supports the hypothesis in the above correlation, however, with no statistically significant relationship between IMP3 expression in dysplastic epithelium or in situ component and invasive malignant tissue. Correlations of IMP3 expression with various pathological characteristics among studied cases is summarized in Table 2.

Table 2: Correlation of IMP3 expression with various pathological characteristics among studied cases

\begin{tabular}{|c|c|c|c|c|c|}
\hline \multirow{2}{*}{$\begin{array}{l}\text { Pathological } \\
\text { characteristics }\end{array}$} & \multicolumn{3}{|c|}{ IMP3 positive } & \multirow[t]{2}{*}{ IMP3 negative } & \multirow[t]{2}{*}{$P$ value } \\
\hline & Weak & moderate & strong & & \\
\hline \multicolumn{6}{|l|}{ Tumor location } \\
\hline Supraglottic & $2(16.7 \%)$ & $3(25 \%)$ & $3(25 \%)$ & $4(33.3 \%)$ & \multirow[t]{4}{*}{0.9210} \\
\hline Glottic & $8(24.2 \%)$ & $5(15.2 \%)$ & $8(24.2 \%)$ & $12(36.4 \%)$ & \\
\hline Subglottic & $0(0 \%)$ & $1(50 \%)$ & $0(0 \%)$ & $1(50 \%)$ & \\
\hline Transglottic & $1(10 \%)$ & $2(20 \%)$ & $2(20 \%)$ & $5(50 \%)$ & \\
\hline \multicolumn{6}{|l|}{ Maximal tumor diameter } \\
\hline$<3.53 \mathrm{~cm}$ & $4(23.5 \%)$ & $2(11.8 \%)$ & $6(35.3 \%)$ & $5(29.4 \%)$ & \multirow{2}{*}{0.7691} \\
\hline$\geq 3.53 \mathrm{~cm}$ & $2(18.1 \%)$ & $3(27.3 \%)$ & $3(27.3 \%)$ & $3(27.3 \%)$ & \\
\hline \multicolumn{6}{|l|}{ Histological grade } \\
\hline Grade I & $0(0 \%)$ & $0(0 \%)$ & $0(0 \%)$ & $4(100 \%)$ & \multirow[t]{3}{*}{0.1938} \\
\hline Grade II & $9(18.4 \%)$ & $10(20.4 \%)$ & $12(24.5 \%)$ & $18(36.7 \%)$ & \\
\hline Grade III & $3(37.5 \%)$ & $2(25 \%)$ & $1(12.5 \%)$ & $2(25 \%)$ & \\
\hline \multicolumn{6}{|l|}{ T stage } \\
\hline $\mathrm{T} 1$ & $2(50 \%)$ & $0(0 \%)$ & $2(50 \%)$ & $0(0 \%)$ & \multirow[t]{4}{*}{0.1905} \\
\hline T2 & $1(12.5 \%)$ & $2(25 \%)$ & $1(12.5 \%)$ & $4(50 \%)$ & \\
\hline T3 & $2(18.2 \%)$ & $1(9.1 \%)$ & $6(54.5 \%)$ & $2(18.2 \%)$ & \\
\hline T4a & $1(20 \%)$ & $2(40 \%)$ & $0(0 \%)$ & $2(40 \%)$ & \\
\hline \multicolumn{6}{|c|}{ Lymph node metastasis } \\
\hline \multicolumn{6}{|l|}{ Positive } \\
\hline N1 & $2(40 \%)$ & $0(0 \%)$ & $1(20 \%)$ & $2(40 \%)$ & \multirow[t]{3}{*}{0.3472} \\
\hline $\mathrm{N} 2$ & $1(25 \%)$ & $0(0 \%)$ & $3(75 \%)$ & $0(0 \%)$ & \\
\hline Negative (NO) & $2(13.4 \%)$ & $3(20 \%)$ & $5(33.3 \%)$ & $5(33.3 \%)$ & \\
\hline \multicolumn{6}{|l|}{ Type of epithelium } \\
\hline Normal & $8(17.4 \%)$ & & & $38(82.6 \%)$ & \multirow[t]{2}{*}{$0.00094^{*}$} \\
\hline Malignant & $23(50 \%)$ & & & $23(50 \%)$ & \\
\hline \multicolumn{6}{|l|}{ Type of epithelium } \\
\hline Normal & $6(23.1 \%)$ & & & $20(76.9 \%)$ & \multirow[t]{3}{*}{$0.0051^{*}$} \\
\hline Dysplastic/ln situ & $17(65.4 \%)$ & & & $9(34.6 \%)$ & \\
\hline Invasive malignancy & $15(57.7 \%)$ & & & $11(42.3 \%)$ & \\
\hline \multicolumn{6}{|l|}{ Type of epithelium } \\
\hline Dysplastic/ln situ & $24(70.6 \%)$ & & & $10(29.4 \%)$ & \multirow[t]{2}{*}{0.79295} \\
\hline Invasive malignancy & $23(67.6 \%)$ & & & $11(32.4 \%)$ & \\
\hline
\end{tabular}

Regarding sensitivity and specificity of IMP-3 expression, sensitivity was $60.66 \%$ (39.34\% are false 
negative results) and specificity was $60.32 \%(39.68 \%$ are false positive results).

\section{Discussion}

SCC is the most common form of cancers among the upper aero-digestive tract malignancies [34]. It is also the most common form of laryngeal carcinomas and accounts for about 85 to $95 \%$ of all laryngeal cancers [8].

IMP3 is an RNA binding protein [35] that is strongly expressed in malignant tumors enhancing tumor cell aggressiveness [36]. The present study evaluated the expression of IMP3 in 61 LSCC cases and correlated the expression of IMP3 with available clinico-pathological data of the studied cases.

The current study showed that positive IMP3 was seen in stromal fibroblasts, smooth muscles and mucus glands of the larynx, and these were considered as positive internal control of IMP3 expression in this study. Membranous staining of IMP3 was noticed in addition to cytoplasmic or nuclear staining. To the best of our knowledge, these findings were not observed in previous studies.

The current study showed that $60.7 \%$ (37/61 cases) were positive for IMP3 expression, which is close to the percent reported by Clauditz et al., 2013, where $55.8 \%$ of LSCC cases, showed positive IMP3 expression [37]. A study was done by Burdelski et al., 2018, on 8877 human cancers and normal tissues, showed that $67 \%$ of LSCC cases showed positive IMP3 expression, a percent which is close to the results of the current study [33]. While Chen et al., 2013, reported positive IMP3 expression in $92 \%$ of the studied cases, and Riener et al., 2017 found that only $40 \%$ of the studied cases showed positive IMP3 expression [29], [38]. These differences may be attributed to the difference in the method used in evaluating IMP3 expression and different scoring systems adopted.

The current study showed that IMP3 positive expression is more common in older ages, supra-glottic location of the tumor, larger tumor sizes, T1 stages, and higher $\mathrm{N}$ stages; however, all these relations did not reach statistical significance. On the contrary, Clauditz et al., 2013, found a significant correlation between IMP3 expression and some clinic-pathologic parameters, as $\mathrm{N}$ stages and proliferation activity of LSCC ( $P$ value $=0.017$ and 0.0071 , respectively), where positive IMP3 expression was found in $81.3 \%$ of N2/N3 cases and in $56.5 \%$ of cases with proliferation rate $\geq 15 \%$ [37]. This is in harmony with our finding of more expression in higher $\mathrm{N}$ stages in the current study, but our inability to reach statistically significant correlation may be attributed to the larger sample size used by them and maybe due to the different clones of the used IMP3. In a study done by Lu et al., 2018 on the expression of IMP3 in ovarian carcinoma of high grade serous, endometrioid and clear cell subtypes, a strong positive correlation was found between IMP3 expression and tumor size and $\mathrm{N}$ stages of all tumor subtypes ( $P$ value $<0.001$ and $<0.05$, respectively), where positive IMP3 expression was found in $74.4 \%$ of tumors $\geq 10 \mathrm{~cm}$ and in $47.8 \%$ of $\mathrm{N} 2$ stages [39]. These findings suggest that IMP3 may play a role in carcinogenesis of different malignant tumors. The frequent finding of correlation between its expression and higher nodal stage points to a possible role in the process of metastasis.

In the present study, (0\%), (63.3\%), and (75\%) of Grades I, II, and III, respectively, were expressers. A non-significant relation was found between degree of differentiation and IMP3 expression ( $P$ value $=0.1938$ ). These results were close to Clauditz et al., 2013, who found that $81.2 \%$ of grade III LSCC cases were IMP3 expressors; however, they reported a significant correlation between IMP3 expression and the histological grade of the tumor [37]. Higher percentages of expression with non-significant differences were reported by Chen et al., 2013 who found positive IMP3 expression in $86 \%, 98 \%$, and $92 \%$ of well, moderately, and poorly differentiated tumors, respectively [29]. Burdelski et al., 2018, found positive correlations between IMP3 expression and high tumor grade and advanced stage in urinary bladder cancers, esophageal adenocarcinomas, and SCC of the lung [33]. All these point to the alleged role of IMP3 in tumor progression, loss of differentiation, and aggressive behavior.

Inthis study, normal epithelium was encountered in 46 cases, $17.4 \%$ showed positive expression of IMP3 in the normal epithelium, and $50 \%$ of malignant tumor tissue showed positive IMP3 expression. There was a statistically significant relationship between IMP3 expression in normal epithelium and underlying malignant tissue $(p<0.00094)$. This was supported by the result of Chen et al., 2013 who found a similar significant correlation [29]. However, he reported negative expression in normal epithelium in $100 \%$ of cases, this difference may be due to different clones of the used IMP3 [29]. The current study also revealed 34 cases that showed dysplastic epithelium or in situ component, $70.6 \%$ of them showed positive expression of IMP3 in the dysplastic epithelium or the in situ component, and $67.6 \%$ of them showed positive expression in concomitant malignant tumor tissue, with no statistically significant correlation ( $p=0.79295)$. Higher percentage was reported by Chen et al., 2013, who found positive expression of IMP3 in $92 \%$ of cases with in situ and invasive components, however, he reported negative expression in mild or moderate dysplasia [29]. This difference may be attributed to the different clones of the used IMP3.

Normal, dysplastic epithelium/in situ component and invasive malignant tissue were all 
present together in 26 cases only in the current study, $23.1 \%$ of them showed positive expression of IMP3 in the normal epithelium, $65.4 \%$ of them showed positive expression of IMP3 in the dysplastic epithelium/in situ component, and $57.7 \%$ of them showed positive expression of IMP3 in the malignant tumor tissue. A statistically significant correlation was found between concomitant IMP3 expression in normal, dysplastic epithelium/in situ component and invasive malignant tissue $(P$ value $=0.0051)$. This result agreed with Chen et al., 2013, and Clauditz et al., 2013, who found a significant correlation as well [29], [37]. These findings suggest that IMP3 plays an important role in tumor carcinogenesis and progression process and thus IMP3 might be targeted by gene therapy.

The current study showed that IMP3 is neither sensitive nor specific for LSCC. The sensitivity was $60.66 \%$, which means that $39.34 \%$ are false negative results. The specificity was $60.32 \%$, which means that $39.68 \%$ are false positive results. These findings were not in harmony with Chen et al., 2013, who found that IMP3 is a marker with high sensitivity and specificity for LSCC [29]. This difference may be due to different clones of the used IMP3 and tumor genetic makeup in different geographic locations.

Burdelski et al., 2018, reported that IMP3 may help in the diagnosis of some cancers, but without sensitivity for these tumors, as hepatocellular carcinoma, melanoma, leiomyosarcoma, papillary, and follicular thyroid carcinomas [33].

\section{References}

1. Jemal A, Bray F, Center MM, Ferlay J, Ward E, Forman D. Global cancer statistics. CA Cancer J Clin. 2011;61(2):69-90. https://doi.org/10.3322/caac.20107 PMid:21296855

2. Siegel RL, Miller KD, Jemal A. Cancer statistics, 2016. CA Cancer J Clin. 2016;66(1):7-30. https://doi.org/10.3322/ caac. 21332

3. Almadori G, Bussu F, Cadoni G, Galli J, Paludetti G, Maurizi M. Molecular markers in laryngeal squamous cell carcinoma: Towards an integrated clinicobiological approach. Eur J Cancer. 2005;41(5):683-93. https://doi.org/10.1016/j.ejca.2004.10.031 PMid: 15763643

4. Hunter KD, Parkinson EK, Harrison PR. Profiling early head and neck cancer. Nat Rev Cancer. 2005;5(2):127-35. https:// doi.org/10.1038/nrc1549

5. Koskinen WJ, Brøndbo K, Dahlstrand HM, Luostarinen T, Hakulinen T, Leivo I, Molijn A, Quint WG, Røysland T, Munck-Wikland E, Mäkitie AA. Alcohol, smoking and human papillomavirus in laryngeal carcinoma: A Nordic prospective multicenter study. Journal of cancer research and clinical oncology. 2007 Sep;133(9):673-8. https://doi.org/10.1007/ s00432-007-0219-8

6. Parkin DM, Bray F, Ferlay J, Pisani P. Global cancer statistics, 2002. CA: a cancer journal for clinicians. 2005 Mar;55(2):74108. https://doi.org/10.3322/canjclin.55.2.74
7. Zhang SY, Lu ZM, Luo XN, Chen LS, Ge PJ, Song XH, Chen $\mathrm{SH}, \mathrm{Wu} \mathrm{YL}$. Retrospective analysis of prognostic factors in 205 patients with laryngeal squamous cell carcinoma who underwent surgical treatment. PLoS One. 2013 Apr 4;8(4):e60157. https://doi.org/10.1371/journal. pone. 0060157

8. Schorn VJ, Miles BA. Laryngeal squamous cell carcinoma InENT Board Prep 2014 (pp. 227-233). Springer, New York, NY https://doi.org/10.1007/978-1-4614-8354-0_20

9. Ibrahim AS, Khaled HM, Mikhail NN, Baraka H, Kamel H. Cancer incidence in Egypt: Results of the national populationbased cancer registry program. J Cancer Epidemiol. 2014;2014:437971. https://doi.org/10.1155/2014/437971

10. Chen X, Gao L, Sturgis EM, Liang Z, Zhu Y, Xia X, Zhu X, Li G, Gao Z. HPV16 DNA and integration in normal and malignant epithelium: Implications for the etiology of laryngeal squamous cell carcinoma. Annals of Oncology. 2017 May 1;28(5):1105-10. https://doi.org/10.1093/annonc/mdx027

11. Maurya SS, Katiyar T, Dhawan A, Singh S, Jain SK, Pant MC, et al. Gene-environment interactions in determining differences in genetic susceptibility to cancer in subsites of the head and neck. Environ Mol Mutagen. 2015;56(3):313-21. https://doi. org/10.1002/em.21920 PMid:25399842

12. Zauri $M$, Berridge G, Thézénas $M L$, Pugh $K M$, Goldin $R$, Kessler BM, et al. CDA directs metabolism of epigenetic nucleosides revealing a therapeutic window in cancer. Nature. 2015;524(7563):114-8. https://doi.org/10.1038/nature14948

13. Rosai J, Ackerman LV. Surgical Pathology. London, New York: Edinburgh; 2004.

14. SEER. Surveillance, Epidemiology, and End Results, 18 Registeries, National Cancer Institute 2016. Available from: http://www.seer.cancer.gov. [Last accessed on 2021 May 26].

15. Dai N, Rapley J, Angel M, Yanik MF, Blower MD, Avruch J. mTOR phosphorylates IMP2 to promote IGF2 mRNA translation by internal ribosomal entry. Genes Dev. 2011;25(11):1159-72. https://doi.org/10.1101/gad.2042311 PMid:21576258

16. Bell JL, Wächter K, Mühleck B, Pazaitis N, Köhn M, Lederer M, et al. Insulin-like growth factor 2 mRNA-binding proteins (IGF2BPs): Post-transcriptional drivers of cancer progression? Cell Mol Life Sci. 2013;70(15):2657-75. https://doi.org/10.1007/ s00018-012-1186-z

PMid:23069990

17. Lederer M, Bley $\mathrm{N}$, Schleifer $\mathrm{C}$, Hüttelmaier $\mathrm{S}$. The role of the oncofetal IGF2 mRNA-binding protein 3 (IGF2BP3) in cancer Semin Cancer Biol. 2014;29:3-12. https://doi.org/10.1016/j. semcancer.2014.07.006

PMid:25068994

18. Wächter $K$, Köhn $M$, Stöhr $N$, Hüttelmaier $S$. Subcellular localization and RNP formation of IGF2BPs (IGF2 mRNAbinding proteins) is modulated by distinct RNA-binding domains. Biol Chem. 2013;394(8):1077-90. https://doi.org/10.1515/ hsz-2013-0111

PMid:23640942

19. Vargas TR, Boudoukha S, Simon A, Souidi M, Cuvellier S, Pinna $\mathrm{G}$, et al. Post-transcriptional regulation of cyclins D1, D3 and G1 and proliferation of human cancer cells depend on IMP-3 nuclear localization. Oncogene. 2014;33(22):2866-75. https://doi.org/10.1038/onc.2013.252 PMid:23812426

20. Ismerim AB, Ferreira SV, Lessa AM, Pereira AS Jr, Gurgel CA Coutinho-Camillo $\mathrm{CM}$, et al. Insulin-like growth factor II messenger RNA-binding protein 3 in Salivary Gland tumors. Appl Immunohistochem Mol Morphol. 2016;24(6):422-6. https:// doi.org/10.1097/pai.0000000000000205 


\section{PMid:26258757}

21. Natkunam $Y$, Vainer G, Chen J, Zhao S, Marinelli RJ, Hammer AS, et al. Expression of the RNA-binding protein VICKZ in normal hematopoietic tissues and neoplasms. Haematologica. 2007;92(2):176-83. https://doi.org/10.3324/haematol.10724 PMid:17296566

22. Köbel M, Xu H, Bourne PA, Spaulding BO, Shih IM, Mao TL, et al. IGF2BP3 (IMP3) expression is a marker of unfavorable prognosis in ovarian carcinoma of clear cell subtype. Modern Pathol. 2009;22(3):469-75. https://doi.org/10.1038/ modpathol.2008.206

PMid:19136932

23. Asioli S, Erickson LA, Righi A, Jin L, Volante M, Jenkins S, et al. Poorly differentiated carcinoma of the thyroid: Validation of the Turin proposal and analysis of IMP3 expression. Modern Pathol. 2010;23(9):1269-78. https://doi.org/10.1038/ modpathol.2010.117

PMid:20562850

24. Lin CY, Chen ST, Jeng YM, Yeh CC, Chou HY, Deng YT, et al. Insulin-like growth factor II mRNA-binding protein 3 expression promotes tumor formation and invasion and predicts poor prognosis in oral squamous cell carcinoma. J Oral Pathol Med. 2011;40(9):699-705. https://doi. org/10.1111/j.1600-0714.2011.01019.x PMid:23647076

25. Hwang YS, Ahn SY, Moon S, Zheng Z, Cha IH, Kim J, et al. Insulinlike growth factor-II mRNA binding protein-3 and podoplanin expression are associated with bone invasion and prognosis in oral squamous cell carcinoma. Arch Oral Biol. 2016;69:25-32. https://doi.org/10.1016/j.archoralbio.2016.05.008 PMid:27232357

26. Ueki A, Shimizu T, Masuda K, Yamaguchi SI, Ishikawa T, Sugihara $\mathrm{E}$, et al. Up-regulation of Imp3 confers in vivo tumorigenicity on murine osteosarcoma cells. PLoS One. 2012;7(11):e50621. https://doi.org/10.1371/journal.pone.0050621 PMid:23226335

27. Samanta S, Pursell B, Mercurio AM. IMP3 protein promotes chemoresistance in breast cancer cells by regulating breast cancer resistance protein (ABCG2) expression. J Biol Chem. 2013;288(18):12569-73. https://doi.org/10.1074/jbc. c112.442319

PMid:23539627

28. Fadare O, Liang SX, Crispens MA, Jones HW, Khabele D, Gwin K, et al. Expression of the oncofetal protein IGF2BP3 in endometrial clear cell carcinoma: Assessment of frequency and significance. Hum Pathol. 2013;44(8):1508-15. https://doi. org/10.1016/j.humpath.2012.12.003

PMid:23465280

29. Chen K, Cornejo KM, Ye W, Wu Q, Liang J, Jiang Z. Oncofetal protein IMP3: A new diagnostic biomarker for laryngeal carcinoma. Hum Pathol. 2013;44(10):2126-31. https://doi. org/10.1016/j.humpath.2013.04.002

PMid:23806529
30. Soddu S, Di Felice E, Cabras S, Castellanos ME, Atzori L, Faa G, Pilloni L. IMP-3 expression in keratoacanthomas and squamous cell carcinomas of the skin: An immunohistochemical study. Eur J Histochem. 2013;57(1):e6. https://doi.org/10.4081/ ejh.2013.e6 PMid:23549465

31. Kim HJ, Kim GE, Lee JS, Lee JH, Nam JH, Choi C. Insulin-like growth factor-II mRNA-binding protein 3 expression in effusion cytology: A marker for metastatic adenocarcinoma cells and a potential prognostic indicator in gastric adenocarcinoma. Acta Cytol. 2014;58(2):167-73. https://doi.org/10.1159/000357199 PMid:24457229

32. Kumar MS, Armenteros-Monterroso E, East $\mathrm{P}$, Chakravorty $\mathrm{P}$, Matthews N, Winslow MM, et al. HMGA2 functions as a competing endogenous RNA to promote lung cancer progression. Nature. 2014;505(7482):212-7. https://doi.org/10.1038/nature12785 PMid:24305048

33. Burdelski C, Jakani-Karimi N, Jacobsen F, Möller-Koop C, Minner S, Simon R, et al. IMP3 overexpression occurs in various important cancer types and is linked to aggressive tumor features: A tissue microarray study on 8,877 human cancers and normal tissues. Oncol Reports. 2018;39(1):3-12. https://doi.org/10.3892/or.2017.6072

PMid:29115542

34. Jonas TJ, Daniel C, Francisco T, Karen HC. Malignant Tumors of the Larynx. Website: EMedicine; 2014. Available from: http://www.emedicine.medscape.com/article/848592overview\#showall. [Last accessed on 2021 May 26].

35. Bhargava S, Visvanathan A, Patil V, Kumar A, Kesari S, Das S, et al. IGF2 mRNA binding protein 3 (IMP3) promotes glioma cell migration by enhancing the translation of RELA/p65. Oncotarget 2017;8(25):40469. https://doi.org/10.18632/oncotarget.17118 PMid:28465487

36. Chen L, Xie Y, Li X, Gu L, Gao Y, Tang L, et al. Prognostic value of high IMP3 expression in solid tumors: A meta-analysis. Onco Targets Ther. 2017;10:2849-63. https://doi.org/10.2147/ott. s128810

PMid:28652767

37. Clauditz TS, Wang CJ, Gontarewicz A, Blessmann M, Tennstedt $\mathrm{P}$, Borgmann $\mathrm{K}$, et al. Expression of insulin-like growth factor II mRNA-binding protein 3 in squamous cell carcinomas of the head and neck. J Oral Pathol Med. 2013;42(2):125-32. https://doi.org/10.1111/j.1600-0714.2012.01178.x PMid:22643116

38. Riener MO, Hoegel J, Iro H, Hartmann A, Agaimy A. IMP3 and p16 expression in squamous cell carcinoma of the head and neck: A comparative immunohistochemical analysis. Oncol Lett. 2017;14(2):1665-70. https://doi.org/10.3892/ol.2017.6352 PMid:28789393

39. Lu L, Wang S, Zhu Q, Qu Y, Gu W, Ning Y, et al. The expression of IMP3 in 366 cases with ovarian carcinoma of high grade serous, endometrioid and clear cell subtypes. Pathol Res Pract. 2018;214(8):1087-94. https://doi.org/10.1016/j.prp.2018.05.026 PMid:29866423 